\title{
Correction to: The Abecedarian Approach to Social, Educational, and Health Disparities
}

\section{Craig T. Ramey ${ }^{1}$}

Published online: 4 June 2018

○) Springer Science+Business Media, LLC, part of Springer Nature 2018 final data analyses concerning possible structural and functional changes in the brain as well as social decision-making behavior expressed during neuroeconomic games. We seek to advance understanding of whether and how early education experiences may contribute to differences in these areas at much later life stages". Hence, the author asks readers to ignore and not to refer any details from this section after the introductory paragraph stating why these topics are theoretically important and well-suited to scientific inquiry using an experimental study design.
The original article can be found online at https://doi.org/10.1007/ s10567-018-0260-y.

\section{Craig T. Ramey}

ctramey@vt.edu

1 Distinguished Research Scholar, Virginia Tech Carilion Research Institute, Professor of Psychology, Neuroscience, Human Development, and Pediatrics, Virginia Tech, VTCRI, 2 Riverside Circle, Roanoke, VA 24016, USA 